\title{
Knowledge and attitudes of primary health care physicians and nurses with regard to population screening for colorectal cancer in Balearic Islands and Barcelona
}

Maria Ramos ${ }^{1 *}$, Magdalena Esteva ${ }^{2}$, Jesús Almeda ${ }^{3,4,5}$, Elena Cabeza ${ }^{1}$, Diana Puente ${ }^{4}$, Rosa Saladich ${ }^{3}$, Albert Boada ${ }^{3}$, Maria Llagostera ${ }^{3}$

\begin{abstract}
Background: Primary health care (PHC) professionals play a key role in population screening of colorectal cancer. The purposes of the study are: to assess knowledge and attitudes among PHC professionals with regard to colorectal cancer screening, as well as the factors that determine their support for such screening.

Methods: Questionnaire-based survey of PHC physicians and nurses in the Balearic Islands and in a part of the metropolitan area of Barcelona.

Results: We collected 1,219 questionnaires. About $84 \%$ of all professionals believe that screening for colorectal cancer by fecal occult blood test (FOBT) is effective. Around $68 \%$ would recommend to their clients a colorectal cancer screening program based on FOBT and colonoscopy. About 31\% are reluctant or do not know.

Professionals perceive the fear of undergoing a colonoscopy as the main obstacle in getting patients to participate, and the invasive nature of this test is the main reason behind their resistance to this program. The main barriers to support the screening program among PHC professionals are lack of knowledge (nurses) and lack of time (physicians). On multivariate analysis, the factors associated with reluctance to recommend colorectal cancer screening were: believing that FOBT has poor sensitivity and is complicated; that colonoscopy is an invasive procedure; that a lack of perceived benefit could discourage client participation; that only a minority of clients would participate; thinking that clients are fed up with screening tests and being unaware if they should be offered something to ensure their participation in the programme.

Conclusions: Two in every three PHC professionals would support a population screening program for colorectal cancer screening. Factors associated with reluctance to recommend it were related with screening tests characteristics as sensitivity and complexity of FOBT, and also invasive feature of colonoscopy. Other factors were related with patients' believes.
\end{abstract}

\section{Background}

Colorectal cancer is an important health problem in developed countries, both because of its high incidence and because it is accompanied by high mortality. In Spain, colorectal cancer ranks first among all cancers in terms of incidence and second in terms of mortality in both sexes together. Every year approximately 25,600

\footnotetext{
* Correspondence: mramos@dgsanita.caib.es

${ }^{1}$ Public Health Department, Balearic Islands Health Department, Spain Full list of author information is available at the end of the article
}

new cases are diagnosed [1] and in 2007 13,416 people died from the disease (INEbase). The annual adjusted incidence rates of colorectal cancer are under the average of the 25-member European Union (UE-25) in men, and especially in women. On the other hand, Spain's adjusted mortality rates are higher than the mean for the UE-25 in men, but lower in women [2].

There is hard evidence that colorectal cancer screening with fecal occult blood test (FOBT) and a colonoscopy on cases with positive FOBT, addressed to the 
population aged 50 to 74 years, effectively reduces colorectal cancer mortality and incidence [3], and clearly fulfills all the criteria of the World Health Organization for the development of a population screening program [4]. The European Union [5,6], together with the US Preventive Services Task Force [7] and the Canadian Task Force on Preventive Health Care [8] have been recommending it for years.

One crucial element for the success of populationbased screening programs is the participation of a large percentage of the population (more than 50\%) [9]. Thus, before a program of this type is implemented, how to ensure compliance is always of great concern. Additionally, it has been noted that individuals who refuse to participate are precisely those at highest risk of developing colorectal cancer [10].

Despite evidence of its effectiveness, organized population screening for colorectal cancer has only been implemented on a national scale in France, the United Kingdom, Finland and northen Italy $[8,11]$. In Spain, pilot tests have been carried out in certain regions, including Catalonia [12]. Experience has shown that PHC physicians play a key role, since people follow their advice when deciding whether to get screened or not $[13,14]$. Nonetheless, according to some studies PHC physicians have preconceived negative attitudes towards colon cancer screening programs that rely on FOBT $[15,16]$. The main reasons [17-21] are their skepticism regarding its effectiveness; concern over false positive and false negative results, i.e., the fear of "doing more harm than good"; doubts about patients' willingness to be tested in the absence of symptoms; lack of time and the added workload that could result from their participation in the program. At the same time, PHC nursing staff can also play an important role in colorectal cancer screening [22] because nurses usually devote more time than other professionals to health education activities [23].

This study is part of a more comprehensive study that aims to assess the knowledge and attitudes of PHC professionals as well as those of their patients with regard to population-based colorrectal cancer screening. The main objective of this first phase is to assess the knowledge and attitudes held by PHC physicians and nurses. Secondly, we want to identify the factors that determine the support afforded by these professionals to population screening for colorectal cancer.

\section{Methods}

\section{Design}

This is a cross-sectional descriptive multicentre study based on a survey conducted among adult care physicians and nurses in a primary health care setting in the Balearic Islands $(1,014,405$ inhabitants in 2007) and in the southern metropolitan area of Barcelona $(1,275,679$ inhabitants in the same year). Since the year 2000, a pilot program for population colorectal cancer screening based on FOBT and colonoscopy has been in place in the southern metropolitan area of Barcelona (115,867 inhabitants).

\section{Study population}

In the Balearic Islands, all 1,001 professionals who were engaged in primary care at the time of the study (491 physicians and 510 nurses) were invited to participate. For the area of Barcelona, with 1,188 professionals (623 physicians and 565 nurses), a sample size was computed. The hypothesis was based on the assumption that $50 \%$ of professionals would support a population screening program. For a confidence level of $95 \%$, and a precision of $5 \%$, the required sample size was 297 physicians and 272 nurses. These were drawn from a convenience sample of health centres, including teaching and nonteaching centres and urban and rural centres.

\section{Data collection}

The research team developed a questionnaire to be selfadministered and based on a literature review [16,22,24]. In March 2008, we performed a pilot study in two health centres, one urban and the other rural, and collected 31 questionnaires that were then used to modify the wording or format of some of the questions. Between the months of April and June 2008, the definitive questionnaire, was completed by the health professionals in their own health center during one of their scheduled meetings. We also used some strategies to capture health professionals who were absent on the day the session was held.

\section{Variables}

We explored the following variables: socio-demographic; professional; knowledge about colorectal cancer; knowledge about cancer screening; the performance of FOBT; attitudes towards implementing a colorectal cancer screening program based on FOBT and colonoscopy for cases with positive stools; perceived obstacles to client participation; reasons, from a professional standpoint, for reluctance to encourage clients to participate; barriers against enlisting the collaboration of PHC professionals and, finally, viewpoints on what to offer professionals to ensure their support to the program. For the knowledge variables and some of the attitudinal variables, the responses given were as follows: "I agree", "I disagree" and "I don't know". On the specific question of whether or not they would support a program of this type, the possible responses were: "Yes, enthusiastically", "Yes, with some reluctance", "No, absolutely not" and "I don't know". Regarding barriers and opportunities, 
the questionnaire offered an array of answers identified in previous studies. For each of the options, the professional could choose "Yes", "No" or "I don't know".

The study obtained the approval from the Primary Health Care Research Committee, the Balearic Islands Ethics Committee of Clinical Research and the IDIAPJordi Gol Ethics Committee. Informed consent to PHC professionals was not considered necessary.

\section{Analysis}

We introduced the questionnaires into a database in Access using Teleform 4.0 for Windows.

In order to assess knowledge and attitudes held by physicians and nurses with regard to colorectal cancer screening, a descriptive analysis was performed. The sample structure was not taken into account in the analysis. We determined the frequencies of the categorical variables and assessed the normality of the continuous variables, whose mean and median we calculated. We carried out a bivariate analysis by type of professional using all variables. We used the chi squared test to compare hypotheses.

Secondly, to identify the factors related with the support afforded by PHC professionals to population screening for colorectal cancer, we carried out a bivariate analysis. Furthermore, a multivariate logistic regression analysis was performed using as dependent variable support or lack of support to the screening programme. Independent variables included were those showing a statistical significance of $\mathrm{p}<0.05$ in bivariate analysis. Backward logistic regression analysis was performed. Independent variables were excluded from the model when there was no statistical significative relationship with the dependent variable and when the estimated coefficients did not change markedly from the previous model with the variable. In addition, each new model was compared with the previous one through the likelihood ratio.

As software we used SPSS 13.0 for Windows.

\section{Results}

We collected 1,219 questionnaires: 675 in the Balearic Islands (response rate: 67,4\%) and 544 in Barcelona ( $95.6 \%$ of the anticipated sample). About $51.4 \%$ were physicians and $48.6 \%$ were nurses; $72.7 \%$ were women. The median age of the professionals was 46 years (interquartile range, IQR: 36-52). The median number of years spent working in PHC was 14 (IQR: 6-20). About 48.9\% of the professionals were fixed staff, $28 \%$ were temporary staff, $12.5 \%$ were substitutes, $2.1 \%$ were residents and in $8.5 \%$ of the cases work status was unknown. About $52 \%$ worked in teaching health centres. The median number of consultations a day was 35 (IQR: $30-40$ ) for physicians and 20 (IQR: 16-25) for nurses.
Interviewees' knowledge and beliefs regarding colorectal cancer, screening programs in general and colorectal cancer screening in particular are presented in Table 1. Professionals' attitudes regarding population screening for colorectal cancer based on testing FOBT and colonoscopy are presented in Table 2 . It stands out that $68 \%$ of all professionals would recommend this programme to their clients and $31 \%$ are reluctant or do not know, with no differences noted between physicians and nurses. The majority (91.4\% of nurses and $83.7 \%$ of physicians) of professionals were familiar with the procedure for FOBT, although only $74.8 \%$ of nurses and $60.6 \%$ of physicians explained to their clients how to perform the test.

About $84.5 \%$ of the PHC physicians and $14.3 \%$ of the PHC nurses had recommended some type of screening test for colorectal cancer to their clients during the previous year. When we asked them to specify which clients, $26 \%$ of professionals who had recommended some type of screening test for colorectal cancer replied that it was those with family antecedents of colorectal cancer, and $23 \%$ that it was those with suspicious clinical symptoms, mainly anemia, rectal bleeding and changes in bowel habit.

The barriers perceived by PHC professionals with respect to population screening for colorectal cancer are shown in Table 3, together with their needs. Fear of having to undergo a colonoscopy is what professionals perceive to be the main obstacle to client participation. Similarly, the invasive nature of colonoscopy is the main reason for professionals' reluctance. The primary barriers in the way of professionals' support the screening program would be lack of knowledge for nurses and lack of time for physicians. What professionals need the most is training and information regarding the program.

In bivariate analysis, several factors were associated with reluctance to support population screening for colorectal cancer, and they had to do with both knowledge and attitudes. We noted no differences by type of professional or area, an exception being the area in which the pilot study is being conducted, where the percentage of professionals who are reluctant to support a screening program for colorectal cancer is smaller than in the rest of the study area.

In the multivariate analysis (Table 4), reluctant professionals were found to be those who believe the FOBT has poor sensitivity and is difficult to perform; that colonoscopy is an invasive procedure; that not perceiving any benefit from screening could deter their clients from participating; that only a minority of their clients would take part in such a program; and, finally, resistance is felt by those who believe clients are fed up with screening tests and those who don't know if they should be offered something to ensure their support to the programme. 
Table 1 Knowledge and beliefs of primary care professionals about colorectal cancer, cancer screening programmes in general, and colorectal cancer screening in particular

\begin{tabular}{|c|c|c|c|c|}
\hline Questions & Answers & $\begin{array}{c}\text { Total } \\
(\%)\end{array}$ & $\begin{array}{l}\text { Physicians } \\
(\%)\end{array}$ & $\begin{array}{c}\text { Nurses } \\
(\%)\end{array}$ \\
\hline \multirow{3}{*}{$\begin{array}{l}\text { Colorectal cancer is the most } \\
\text { common cancer in both sexes } \\
\text { together }\end{array}$} & I agree & 58.5 & 69.0 & 47.1 \\
\hline & I disagree & 17.9 & 17.8 & 18.1 \\
\hline & $\begin{array}{l}\text { I don't } \\
\text { know }\end{array}$ & 23.6 & 13.2 & 34.8 \\
\hline $\begin{array}{l}\text { Colorectal cancer is one of the } \\
\text { three leading causes of death }\end{array}$ & I agree & 77.6 & 87,5 & 66,9 \\
\hline
\end{tabular}

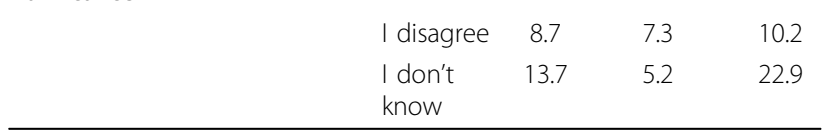

\begin{tabular}{lllll}
\hline About half of all people who & I agree & 69.6 & 80.1 & 58.3
\end{tabular}
have colorectal cancer are still alive 5 years after the diagnosis

\begin{tabular}{lllll} 
I disagree & 8.1 & 8.3 & 8.0 \\
I don't & 22.3 & 11.6 & 33.7 \\
know & & & \\
\hline
\end{tabular}

\begin{tabular}{lllll}
\hline The early diagnosis of & I agree & 90.5 & 95.4 & 85.0
\end{tabular}

colorectal cancer, before the

onset of symptoms, is a

prognostic factor

\begin{tabular}{|c|c|c|c|c|}
\hline & I disagree & 4.0 & 2.5 & 5.7 \\
\hline & $\begin{array}{l}\text { I don't } \\
\text { know }\end{array}$ & 5.5 & 2.1 & 9.3 \\
\hline
\end{tabular}

The rapid diagnosis of colorectal cancer, after the

l agree $\quad 80.9 \quad 84.3 \quad 76.0$

onset of symptoms, is a

prognostic factor

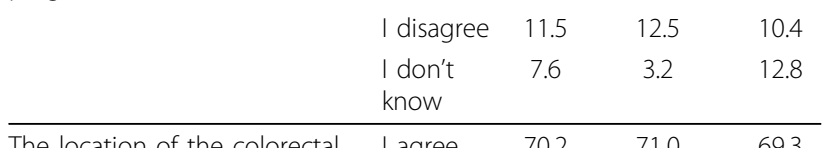

cancer (colon or rectum) is a

prognostic factor

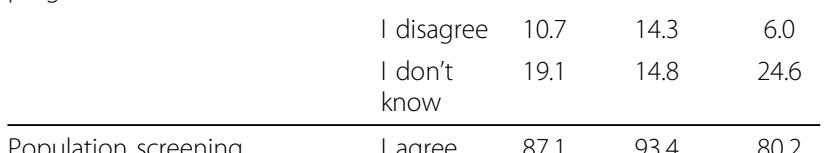

Population screening

programmes target

asymptomatic subjects of

specific age groups

\begin{tabular}{llllc} 
& $\begin{array}{l}\text { I disagree } \\
\text { I don't } \\
\text { know }\end{array}$ & 5.0 & 3.7 & 6.3 \\
& & 2.9 & 13.5 \\
\hline $\begin{array}{l}\text { The purpose of a population } \\
\text { screening programme is to } \\
\text { reduce the mortality rate }\end{array}$ & I agree & 85.4 & 86.9 & 83.7 \\
& & & & \\
& $\begin{array}{l}\text { I disagree } \\
\text { I don't } \\
\text { know }\end{array}$ & 11.0 & 10.4 & 11.6 \\
\hline
\end{tabular}

Table 1 Knowledge and beliefs of primary care professionals about colorectal cancer, cancer screening programmes in general, and colorectal cancer screening in particular (Continued)

\begin{tabular}{llll}
\hline A screening programme's & I agree & 70.0 & 76.5
\end{tabular}
effectiveness depends on the

$\%$ of the population that participates in it

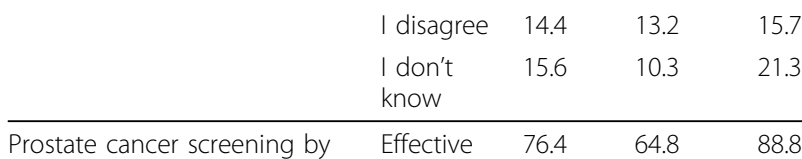

testing for prostate-specific

antigen (PSA) is...

\begin{tabular}{|c|c|c|c|c|}
\hline & Ineffective & 20.4 & 34.1 & 5.9 \\
\hline & $\begin{array}{l}\text { I don't } \\
\text { know }\end{array}$ & 3.2 & 1.1 & 5.3 \\
\hline Breast cancer screening by & Effective & 98.3 & 99.2 & 97.4 \\
\hline & Ineffective & 0.6 & 0.5 & 0.7 \\
\hline & $\begin{array}{l}\text { I don't } \\
\text { know }\end{array}$ & 1.1 & 0.3 & 1.9 \\
\hline Lung cancer screening by & Effective & 78 & 67.2 & 89.5 \\
\hline & Ineffective & 15.3 & 27.1 & 2.7 \\
\hline & $\begin{array}{l}\text { I don't } \\
\text { know }\end{array}$ & 6.7 & 5.7 & 7.7 \\
\hline Screening for colorectal cancer & Effective & 60.1 & 57.3 & 63 \\
\hline & Ineffective & 30.1 & 39.5 & 20 \\
\hline & $\begin{array}{l}\text { I don't } \\
\text { know }\end{array}$ & 9.9 & 3.3 & 17 \\
\hline
\end{tabular}

\begin{tabular}{lllll}
\hline Screening for colorectal cancer & Effective & 83.9 & 83.1 & 84.7
\end{tabular}

by testing for occult blood in

stools (FOBT) is...

\begin{tabular}{|c|c|c|c|c|}
\hline & Ineffective & 11.3 & 15.1 & 7.1 \\
\hline & $\begin{array}{l}\text { I don't } \\
\text { know }\end{array}$ & 4.9 & 1.8 & 8.2 \\
\hline \multirow{3}{*}{$\begin{array}{l}\text { Screening for colorectal cancer } \\
\text { by means of colonoscopy is... }\end{array}$} & Effective & 96.3 & 97.7 & 94.6 \\
\hline & Ineffective & 1.0 & 1.6 & 0.3 \\
\hline & $\begin{array}{l}\text { I don't } \\
\text { know }\end{array}$ & 2.8 & 0.6 & 5 \\
\hline \multirow{3}{*}{$\begin{array}{l}\text { The FOBT is too risky to be a } \\
\text { screening test }\end{array}$} & I agree & 4.3 & 3.0 & 5.7 \\
\hline & I disagree & 83.3 & 92.4 & 72.7 \\
\hline & $\begin{array}{l}\text { I don't } \\
\text { know }\end{array}$ & 12.5 & 4.6 & 21.5 \\
\hline \multirow{3}{*}{$\begin{array}{l}\text { Colonoscopy is too risky to be } \\
\text { a screening test }\end{array}$} & I agree & 33.4 & 36.6 & 29.8 \\
\hline & I disagree & 48.9 & 54.2 & 42.9 \\
\hline & $\begin{array}{l}\text { I don't } \\
\text { know }\end{array}$ & 17.6 & 9.2 & 27.4 \\
\hline
\end{tabular}


Table 2 Primary care professionals' attitudes towards population screening for colorectal cancer

\begin{tabular}{llccc}
\hline Questions & Answers & $\begin{array}{c}\text { Total } \\
\text { (\%) }\end{array}$ & $\begin{array}{c}\text { Physicians } \\
\text { (\%) }\end{array}$ & $\begin{array}{c}\text { Nurses } \\
\text { (\%) }\end{array}$ \\
\hline If a programme for & Yes, enthusiastically & 68.5 & 69.2 & 67.8 \\
population & & & & \\
colorectal cancer & & & & \\
screening based on & & & \\
FOBT and & & & \\
colonoscopy were \\
implemented, would
\end{tabular}

you recomend it?

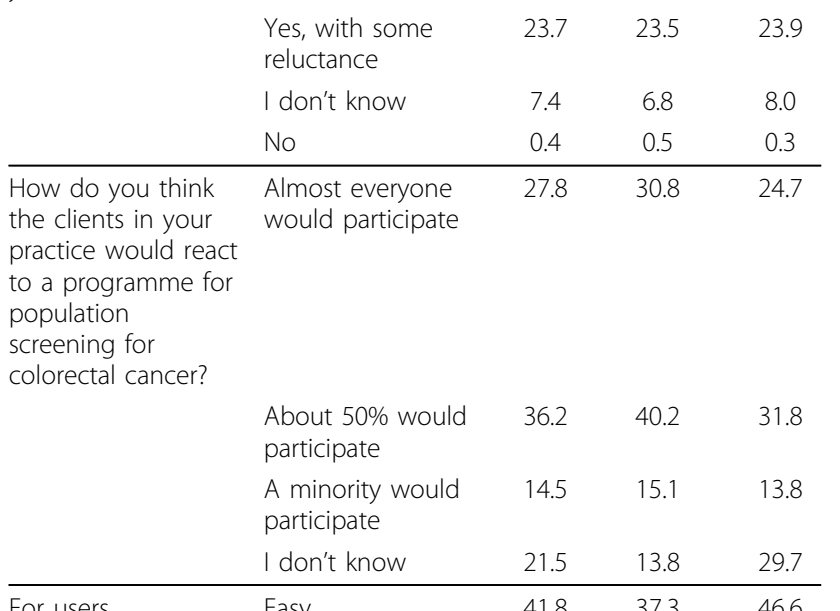

performing the

FOBT is...

\begin{tabular}{|c|c|c|c|c|}
\hline & $\begin{array}{l}\text { Neither easy nor } \\
\text { hard }\end{array}$ & 40.8 & 42.4 & 39.0 \\
\hline & Complicated & 14.2 & 16.9 & 11.2 \\
\hline & I don't know & 3.3 & 3.4 & 3.3 \\
\hline $\begin{array}{l}\text { What role do you } \\
\text { think you could play } \\
\text { in a colorectal } \\
\text { cancer screening } \\
\text { programme?* }\end{array}$ & $\begin{array}{l}\text { General awareness- } \\
\text { raising among } \\
\text { clients about } \\
\text { colorectal cancer } \\
\text { and screening }\end{array}$ & 92.2 & 90.8 & 93.6 \\
\hline & $\begin{array}{l}\text { Individual } \\
\text { counseling for } \\
\text { reluctant clients }\end{array}$ & 91.5 & 93.4 & 89.4 \\
\hline & $\begin{array}{l}\text { Sending clients to } \\
\text { the programme if } \\
\text { they have not } \\
\text { received the letter }\end{array}$ & 77.6 & 77.9 & 77.2 \\
\hline & Capturing clients & 74.3 & 74.1 & 74.5 \\
\hline & $\begin{array}{l}\text { Signing letters } \\
\text { inviting clients to } \\
\text { join the programme }\end{array}$ & 45.7 & 49.7 & 41.1 \\
\hline
\end{tabular}

* professionals who agree with each statement, versus those who disagree + don't know.

\section{Discussion}

We have explored the knowledge and attitudes of PHC professionals from two regions in Spain regarding population screening for colorectal cancer. We have obtained two kinds of responses: the ones associated to the professionals themselves, and the ones derived from their role as patient's advocates, that is, their opinion about how their patients would react towards a colorectal cancer screening programme. Patient's attitudes will be more thoroughly explored during the next phase of this study in which general population will be surveyed and interviewed.

In Spain, National Cancer Strategy [25] is promoting the development of population screening programs for colorectal cancer. Several regions are currently implementing them. All but one are centralized programs, in which PHC professionals play an insignificant role. The Basque country program, the only one pivoted around PHC professionals, is the one that until now has obtained the highest rates of participation, around 59\% (data not published). In Cataluña, the pilot program for population colorectal cancer screening has used the guaiac FOBT test, obtaining low rates of participation in the first rounds, $17.5 \%$ in the first round and $22.3 \%$ in the second one [26]. Currently, the Cataluña Health Department has decided to move to the immunological FOBT test, used also in the other programs in Spain. In Balearic Island, such decision has not yet taken. Instead, the importance of pivoting the program around PHC professionals is clear for the Balearic Health Department, following the basque and the french models [27].

The strategy we followed yielded higher rates of PHC worker participation than we had expected in light of previous studies $[16,28]$, which suggests that the subject is of interest to these workers. However, a $23 \%$ of professionals in Balearic Islands didn't answer the questionnaire. This fact can have produced a selection bias, since those who have not answered are probably the most skeptical. Another noteworthy limitation of the study is that we may have incurred in what may be referred to as "the public health expert's bias", since some of the questionnaire items were very technical and particularly difficult for nursing staff. However, when we designed the questionnaire we felt that anyone supporting a screening program has to be familiar with the health problem targeted by the program, the features of the test involved (sensitivity and specificity) and the programme expected benefits.

Most PHC physicians and nurses believe that colorectal cancer screening with FOBT is effective, although more than half of the physicians and most nurses also consider effective prostate cancer screening with prostate-specific antigen (PSA) and lung cancer screening with CAT scan. This casts doubt on their knowledge regarding the available evidence on the effectiveness of screening programs for different types of cancer. On the other hand, when we asked them if they had recommended some type of screening test for colorectal cancer to their clients over the previous year, most physicians said yes. Nonetheless, when asked to specify which clients, some professionals replied that it was 
Table 3 Barriers and needs surrounding population screening for colorectal cancer as perceived by primary care professionals*

\begin{tabular}{lccc}
\hline Questions & $\begin{array}{c}\text { Total } \\
\text { (\%) }\end{array}$ & $\begin{array}{c}\text { Physicians } \\
\text { (\%) }\end{array}$ & $\begin{array}{c}\text { Nurses } \\
\text { (\%) }\end{array}$ \\
\hline ¿What obstacles do you think we would & & & \\
encounter in trying to get your clients to & & & \\
participate? & & & 68.6 \\
Fear of having to undergo a colonoscopy & 71.1 & 73.3 & 64.4 \\
Lack of knowledge about colorectal cancer & 66.7 & 59.3 & 70.3 \\
Fear of having a colorectal cancer found & 60.2 & 60.1 & 60.3 \\
The complicated nature of the procedure & 41.9 & 49.3 & 33.7 \\
$\begin{array}{l}\text { Dislike or repulsion at having to handle } \\
\text { stools }\end{array}$ & 22.6 & 26.3 & 18.6 \\
$\begin{array}{l}\text { Perceiving no benefit } \\
\text { Lack of trust in the public health system }\end{array}$ & 6.2 & 6.4 & 5.9 \\
\hline What would make you reluctant to & & & \\
encourage your clients to participate? & & & \\
Colonoscopy is an invasive procedure & 60.9 & 56.4 & 65.8 \\
The anxiety generated by false positive & 45.9 & 43.5 & 48.6 \\
results & & & \\
The fact that clients are fed up with & 33.5 & 34.4 & 32.5 \\
screening tests & & & \\
The false sense of security from false & 29.5 & 35.8 & 22.6 \\
negative results & & & \\
\hline
\end{tabular}

¿What are the main barriers to getting

PHC professionals to support the screening program?

\begin{tabular}{|c|c|c|}
\hline Lack of time & 88.9 & 93.6 \\
\hline Professional burnout & 62.5 & 70.0 \\
\hline $\begin{array}{l}\text { Difficulty in explaining this information to } \\
\text { him/her }\end{array}$ & 34.2 & 38.3 \\
\hline $\begin{array}{l}\text { Lack of knowledge about screening } \\
\text { programmes }\end{array}$ & 33.9 & 26.3 \\
\hline $\begin{array}{l}\text { Participation in other screening } \\
\text { programmes }\end{array}$ & 26.3 & 23.0 \\
\hline Lack of knowledge about colorectal cancer & 24.8 & 15.4 \\
\hline Being disinterested in the matter & 18.3 & 16.4 \\
\hline
\end{tabular}

¿What do you think professionals should be offered to ensure their support?

Training on colorectal cancer and screening

Detailed information about the programme

More time with each patient during patient visits

$\begin{array}{llll}\text { Regular feedback about the results } & 92.9 & 93.8 & 91.8\end{array}$

$\begin{array}{llll}\text { Collaboration in writing papers } & 74.1 & 76.6 & 71.4\end{array}$

$\begin{array}{llll}\text { Economic compensation } & 43.8 & 37.1 & 51.1\end{array}$

$\begin{array}{llll}\text { Nothing, since it is part of their work } & 22.0 & 23.0 & 20.9\end{array}$

*professionals who agree with each statement versus those who disagree + don't know.

those who had symptoms suggestive of colorectal cancer, which leads us to suspect that they do not fully understand what screening means. This is an important issue because lack of knowledge about the concept of population based screening programme was associated in the multivariant analysis to reluctance to support it.

Around $70 \%$ of primary care workers would enthusiastically support a population screening program for colorectal cancer based on a FOBT and a colonoscopy for cases with positive stools. This result is better than the one obtained in other countries such as Australia (50\%) [24]. Another positive finding was that most professionals felt that their role in this type of program might be to raise general awareness among clients and counsel the ones showing reluctance. On the other hand, signing letters of invitation to join the program, a strategy that has effectively improved participation [29], was mentioned by less than half of all professionals, perhaps because Spanish physicians and nurses, and especially the former, dislike administrative tasks.

The main barriers expressed by PHC professsionals for supporting a colorectal cancer screening program were lack of knowledge among nurses and lack of time among physicians. Both aspects emerged in a previous qualitative study [21]. While improving the first factor is feasible, changing the second one is difficult in the short run. This, however, could be one more reason to leave nurses in charge of raising general awareness among users and counseling those harboring doubts, as the physicians themselves have suggested [30], especially since nurses appear to be more familiar than physicians with the procedure of FOBT, a factor that could also render them more willing to participate. In the United States, on the other hand, nurses' involvement in colorectal cancer screening is more geared towards performing sigmoidoscopies [31].

Health workers perceive the fear of having to undergo a colonoscopy as the most important barrier to client participation in a colorectal cancer screening program. This parallels their own reluctance, since they consider the procedure invasive and too hazardous for a screening test. The results of pilot studies carried out in Spain have shown that colonoscopy is acceptable to a high percentage - around $89 \%$ - of those who test positive for FOBT [26]. Despite this, health professionals and clients should be fully aware of the risks and complications of colonoscopy before subscribing to a program [32], and they should also be aware of its benefits, since this may encourage participation among professionals and, through their influence, among clients as well [33].

Besides from the invasive feature of colonoscopy, poor sensitivity and complicated procedure of FOBT were associated to reluctance to support a colorectal cancer screening program. FOBT poor sensitivity was also associated to supporting a colorectal cancer screening program in other studies $[16,20]$, and also belief in FOBT test efficacy [24]. Clearly, immunological test improve guaiac test in both aspects [34]. Other factors associated 
Table 4 Multivariate analysis of factors associated with being reluctant to support a population screening programme based on testing for occult blood in stools and colonoscopy*

\begin{tabular}{lllrr}
\hline Variable & Categories & p & OR & $\begin{array}{r}\mathbf{9 5 \%} \\
\text { Cl }\end{array}$ \\
\hline $\begin{array}{l}\text { Population screening } \\
\text { programmes target } \\
\text { asymptomatic } \\
\text { subjects of specific age groups }\end{array}$ & I agree & 0.041 & 1 & \\
& & & & \\
\end{tabular}

subjects of specific age groups

\begin{tabular}{|c|c|c|c|c|}
\hline & I don't know & 0.043 & 2.11 & $\begin{array}{r}1.02 \\
4.35\end{array}$ \\
\hline & I disagree & 0.092 & 1.69 & $\begin{array}{r}0.91- \\
3.12\end{array}$ \\
\hline \multirow{3}{*}{$\begin{array}{l}\text { Test for occult blood in stools } \\
\text { (FOBT) has poor sensitivity }\end{array}$} & No & 0.008 & 1 & \\
\hline & I don't know & 0.018 & 1.88 & $\begin{array}{r}1.11- \\
3.17\end{array}$ \\
\hline & Yes & 0.004 & 1.71 & $\begin{array}{r}1.18- \\
2.48\end{array}$ \\
\hline \multirow{3}{*}{$\begin{array}{l}\text { Test for occult blood in stools } \\
\text { (FOBT) has poor specificity }\end{array}$} & No & 0.022 & 1 & \\
\hline & I don't know & 0.467 & 0.80 & $\begin{array}{r}0.45- \\
1.44\end{array}$ \\
\hline & Yes & 0.055 & 1.48 & $\begin{array}{r}0.99- \\
2.21\end{array}$ \\
\hline \multirow{4}{*}{$\begin{array}{l}\text { For users, performing the FOBT } \\
\text { is... }\end{array}$} & Easy & 0.002 & 1 & \\
\hline & $\begin{array}{l}\text { Neither easy nor } \\
\text { hard }\end{array}$ & 0.009 & 1.62 & $\begin{array}{r}1.12 \\
2.32\end{array}$ \\
\hline & I don't know & 0.008 & 3.26 & $\begin{array}{r}1.36- \\
7.84\end{array}$ \\
\hline & Complicated & 0.002 & 2.06 & $\begin{array}{c}1.2 \\
3 .\end{array}$ \\
\hline \multirow{4}{*}{$\begin{array}{l}\text { How would people react to a } \\
\text { population screening } \\
\text { programme for colorectal } \\
\text { cancer? }\end{array}$} & $\begin{array}{l}\text { Almost everyone } \\
\text { would } \\
\text { participate }\end{array}$ & 0.000 & 1 & \\
\hline & $\begin{array}{l}\text { About } 50 \% \\
\text { would } \\
\text { participate }\end{array}$ & 0.000 & 2.58 & $1.61-$ \\
\hline & $\begin{array}{l}\text { A minority } \\
\text { would } \\
\text { participate }\end{array}$ & 0.000 & 5.64 & 3.2 \\
\hline & I don't know & 0.000 & 4.61 & \\
\hline
\end{tabular}

What barriers to client participation would we encounter?

\section{- Perceiving no benefit}

I disagree
I don't know
I agree

$\begin{array}{rrr}0.001 & 1 & \\ 0.002 & 1.99 & 1.28- \\ & & 3.07 \\ 0.011 & 1.71 & 1.13- \\ & & 2.58\end{array}$

What would make you reluctant to enourage clients to participate?
Table 4 Multivariate analysis of factors associated with being reluctant to support a population screening programme based on testing for occult blood in stools and colonoscopy* (Continued)

\begin{tabular}{|c|c|c|c|c|}
\hline & I don't know & 0.555 & 1.17 & $\begin{array}{r}0.69- \\
1.99\end{array}$ \\
\hline & I agree & 0.000 & 2.25 & $\begin{array}{r}1.59- \\
3.17\end{array}$ \\
\hline \multirow{3}{*}{$\begin{array}{l}\text { - Colonoscopy is an invasive } \\
\text { procedure }\end{array}$} & I disagree & 0.051 & 1 & \\
\hline & I don't know & 0.781 & 1.13 & $\begin{array}{c}0.47- \\
2.71\end{array}$ \\
\hline & I agree & 0.017 & 1.53 & $\begin{array}{r}1.08- \\
2.18\end{array}$ \\
\hline $\begin{array}{l}\text { What do you think professionals } \\
\text { hould be offered to ensure } \\
\text { heir support to the screening } \\
\text { orogram? }\end{array}$ & & & & \\
\hline \multirow{3}{*}{$\begin{array}{l}\text { - Nothing, since it is part of } \\
\text { their work }\end{array}$} & I agree & 0.113 & 1 & \\
\hline & I don't know & 0.041 & 1.56 & $\begin{array}{r}1.01- \\
2.41\end{array}$ \\
\hline & I disagree & 0.344 & 1.30 & $\begin{array}{r}0.75- \\
2.25\end{array}$ \\
\hline
\end{tabular}

with reluctance were related with PHC professional's believes about their patient's participation and tiredness with screening procedures. Both will be explored in depth in the next phase of the study.

\section{Conclusions}

Two in every three PHC professionals would support a population screening program for colorectal cancer screening. Factors associated with reluctance to recommend it were related with screening test characteristics as sensitivity and complexity of FOBT and with invasive feature of colonoscopy. Other factors were related with patients' believes. Training programs will be needed before the population screening is launched, in order to maximize health professional's support.

\section{Acknowledgements}

This study received two grants from the Fondo de Investigaciones Sanitarias [Health Research Fund] of Spain's Ministerio de Sanidad y Consumo [Ministry of Health and Consumer Affairs] (PI 07/905 y PI 07/90696). It also received funding from the Red de Investigación en Promoción de la Salud y Actividades Preventivas de Atención Primaria [Health Promotion and Primary Care Prevention Activities Research Network] (red IAPP), supported by Spain's Ministerio de Sanidad y Consumo (ISCIII-RETCI G03/170 y RD 06/ 0018), as well as from the Instituto Universitario de Investigación en Ciencias de la Salud [University Institute for Health Sciences Research] (IUNICS). Other members of the research team are: Maria Martín-Rabadán, Maties Torrent, Guillem Artigues, Maria Taltavull, Joana Maria Vanrell, Ma Jesús Gallardo, Pilar Piñeiro, Francesc Xavier Cantero, Belen Eguinoa, Manel Segarra and Joan Carles Contel.

Author details

'Public Health Department, Balearic Islands Health Department, Spain.

${ }^{2}$ Mallorca Primary Health Care Service, Balearic Island Health Service, Spain. 
${ }^{3}$ Costa de Ponent Primary Health Care Department, Catalonian Health Institut, Barcelona, Spain. ${ }^{4}$ IDIAP-Jordi Gol, Barcelona, Spain. ${ }^{5} \mathrm{CIBER}$, Epidemiology and Public Health (CIBERESP), Spain.

\section{Authors' contributions}

MR, ME and EC designed the study; MR and ML liderated the development of the study in Balearic Islands and Barcelona respectively; RS and AB coordinated the development of the study in their respective health areas; $M R, M E, E C$ and JA performed the statistical analysis; MR, DP and JA draft the manuscript. ME, EC, RS, AB and ML review critically the draft. All authors read and approved the final manuscript.

\section{Competing interests}

The authors declare that they have no competing interests.

Received: 6 October 2009 Accepted: 20 September 2010 Published: 20 September 2010

\section{References}

1. Centro Nacional de Epidemiología: Instituto de Salud Carlos III: La situación del cáncer en España. Madrid: Ministerio de Sanidad y Consumo 2005.

2. Ferlay J, Autier P, Boniol M, Heanue M, Colombet M, Boyle P: Estimates of the cancer incidente and mortality in Europe in 2006. Annals Oncol 2007, 18:581-92.

3. Winawer S, Faivre J, Selby J, Bertaro L, Chen THH, Kroborg O, Levin B, Mandel J, O'Morain C, Richards M, Rennert G, Russo A, Saito H, Semigfnovsky B, Wong B, Smith R: Workgroup II: the screening process. UICC International Workshop on Facilitating Screening for Colorectal Cancer, Oslo, Norway (29 and 30 June 2002). Ann Oncol 2005, 16:31-3.

4. Boyle P, Vainio H, Smith R, Benamouzig R, Lee WC, Segnan N, et al: Workgroup I: criteria for screening. UICC International Workshop on Facilitating Screening for Colorectal Cancer, Oslo, Norway (29 and 30 june 2002). Ann Oncol 2005, 16:25-30.

5. Boyle P, Autier P, Bartelink H, Baselga J, Boffetta P, Burn J, Gurns HJG, Christensen L, Denis L, Dicato M, Diehl V, Doll R, Franceschi S, Gillis CR, Gray N, Griciute L, Hackshaw A, Kasler M, Kogevinas M, Kvinnsland S, La Vecchia C, Levi F, McVie JG, Maisonneuve P, Martin-Moreno JM, Newton Bishop J, Oleari F, Perrin P, Quinn M, Richards M, Ringborg U, Scully C, Siracka E, Storm H, Tubiana M, Tursz T, Veronesi U, Wald N, Weber W, Zaridze DG, Zatonski W, i zur Hausen H: European Code Against Cancer and scientific justification: third version (2003). Ann Oncol 2003, 14:973-1005

6. Von Karsa L, Antila A, Ronco G, Ponti A, Malila N, Harbin M, Segnan N, Castillo-Beltran M, Boniol M, Ferlay J, Hery C, Sauvaget C, Voti L, Autier P: Cancer screening in the European Union. Report of the implementation of the Council Recommendation on cancer screening - First Report. Luxembourg: European Commission 2008 [http://ec.europa.eu/health/ ph_determinants/genetics/cancer_screening_es.pdf], ISBN 978-92-79-089344.

7. Pignone M, Rich M, Teutsch SM, Berg AO, Lohr KN: Screening for colorectal cancer in adults at average risk; A summary of the evidence. Ann Intern Med 2002, 137(2):132-41.

8. Preventive Health Care: Colorectal cancer screening: Recommendation statement from the Canadian Task Force on Preventive Health Care. CMAJ 2001, 165(2):206-8.

9. Goulard H, Boussac-Zarebska M, Bloch J: Epidemiological assessment of the pilot program for organized colorectal cancer screening, France, 2007. Bulletin épidémiologique hebdomadaire 2009, 2-3:22-5.

10. Herbert C, Launoy G, Gignoux M: Factors affecting compliance with colorectal cancer screening in France: differences between intention to participate and actual participation. Eur I Cancer Prev 1997, 6:44-52.

11. Faivre J, Lepage $C$, Dancourt V: Le dépistage organisé du cancer colorectal en France et en Europe: historique et état des lieux. Bulletin épidémiologique hebdomadaire 2009, 2-3:17-9.

12. Navarro M, Peris M, Binefa G, Vanaclocha M, Losa F, Fernandez E: Cáncer colorrectal en una población con un programa de cribado basado en la prueba del guayaco. Med Clin (Barc) 2009, 132(13):495-500.

13. Hiatt R, Wardle J, Vernon S, Austoker J, Bistanti L, Fox S, Gnauck R, Iverson D, Mandelson M, Reading D, Smith R: Workgroup IV: public education. UICC International Workshop on Facilitating Screening for
Colorectal Cancer, Oslo, Norway (29 and 30 June 2002). Ann Oncol 2005, 16:38-41.

14. Cabeza E, Catalán G, Avellà G, Llobera J, Pons O: Conocimientos, creencias y actitudes de la población femenina de Mallorca respecto al cáncer. Rev Esp Salud Pública 1999, 73:489-99.

15. Hynam KA, Hart AR, Gay SP, Inglis A, Wicks AC, Mayberry JF: Screening for colorectal cancer: reason for refusal of faecal occult blood testing in a general practice in England. J Epidemiol Com Health 1995, 49(1):84-6.

16. Federici A, Rossi PG, Bartolozzi F, Farchi S, Borgia P, Guastcchi G: Survey on colorectal cancer screening knowledge, attitudes, and practices of general practice physicians in Lazio, Italy. Prev Med 2005, 41:30-5.

17. Berry S, Arroll B, Fraser A, Weller D: Screening for colorectal cancer: a survey of New Zealand general practitioners. New Z Med J 1996, 109(1034):447-9.

18. Launoy G, Veret JL, Richir B, Reaud JM, Ollivier V, Valla A, Gignoux M: Involvement of general practitioners in mass screening. Experience of a colorectal cancer mass screening program in the Calvados region (France). Eur J Cancer Prev 1993, 2:229-32.

19. Tudiver F, Guibert R, Haggerty J, Ciampi A, Medved W, Brown JB, Herbert C, Katz A, Ritvo P, Grant B, Goel V, Smith P, O'Beirne M, Williams II, Moliner P: What influences family physicians' cancer screening decisions when practice guidelines are unclear or conflicting? J Fam Pract 2002, 51(9):760

20. Berchi C, Dupuis JM, Launoy G: The reasons of general practitioners for promoting colorectal cancer mass screening in France. Eur I Health Econ 2005, 7:91-8.

21. Goel V, Gray R, Chart P, Fitch M, Saibil F, Zdanowicz Y: Perspectives on colorectal cancer screening: a focus group study. Health Expect 2004, 7:51-60.

22. Klabunde CN, Frame PS, Meadow A, Jones E, Nadel M, Vernon SW: A nacional survey of primary care physicians' colorectal cancer screening recommendations and practices. Prev Med 2003, 36:352-62.

23. March S, Ramos M, Soler M, Ruíz-Jiménez JL: Revisión documental de experiencias de actividad comunitaria en atención primaria. Aten Primaria .

24. Tong S, Hughes K, Oldenburg B, Del Mar C: Would general practitioners support a population-based colorectal cancer screening program of faecal-occult blood testing? Intern Med J 2004, 34:532-8.

25. Estrategia en Cáncer del Sistema Nacional de Salud. Ministerio de Sanidad y Consumo. [http://www.msc.es/organizacion/sns/planCalidadSNS/ pdf/excelencia/cancer-cardiopatia/CANCER/opsc_est1.pdf.pdf].

26. Peris $M$, Espinàs $J A$, Muñoz $L$, Navarro $M$, Binefa $G$, Borràs $J M$, Catalan Colorectal Cancer Screening Pilot Program Group: Lessons learnt from a population-based pilot program for colorectal screening in Catalonia (Spain). J Med Screen 2007, 14:81-6.

27. Viguier J: L'organisation du dépistage du cancer colorectal en France. Bulletin épidémiologique hebdomadaire 2009, 2-3:19-22.

28. Esteva M, Larraz C, Jimenez F: La salud mental en los médicos de familia: efectos de la satisfacción y estrés en el trabajo. Rev Clin Esp 2006, 206:77-83.

29. Cole SR, Young GP, Byrne D, Guy JR, Morcom J: Participation in screening for colorectal cancer based on a faecal occult blood test is improved by endorsement by the primary care practitioner. J Med Screen 2007, 9:147-52.

30. Woodrow C, Rozmovits L, Hewitson P, Rose P, Austoker J, Watson E: Bowel cancer screening in England: a qualitative study of GP's attitudes and information needs. BMC Family Practice 2006, 7:53.

31. Shaheen NJ, Crosby MA, O'Malley MS, Murray SC, Sandler RS, Galanko JA, Ransohoff DF, Klenzak JS: The practices and attitudes of primary care nurse practitioners and physician assistants with respect to colorectal cancer screening. Am J Gastroenterol 2000, 95(11):3259-64.

32. Gotzsche PC, Hartling OJ, Nielsen M, Brodersen J, Jorgensen KJ: Breast screening: the facts- or maybe not. BMJ 2009, 338:446-8.

33. Launoy G, Veret JL, Richir B, Reaud JM, Ollivier V, Valla A, Gignoux M: Involvement of general practitioners in mass screening. Experience of a colorectal cancer mass screening program in the Calvados region (France). Eur J Cancer Prev 1993, 2:229-32.

34. Van Rossum $L G$, van Rijn $A F$, Laheij $R J$, van Oijen $M G$, Fockens $P$, van Krieken HH, Verbeek AL, Jansen JB, Dekker E: Random comparison of guaiac and immunochemical fecal occult blood tests for colorectal cancer in an screening population. Gastroenterol 2008, 135:82-90. 


\section{Pre-publication history}

The pre-publication history for this paper can be accessed here:

http://www.biomedcentral.com/1471-2407/10/500/prepub

doi:10.1186/1471-2407-10-500

Cite this article as: Ramos et al: Knowledge and attitudes of primary

health care physicians and nurses with regard to population screening

for colorectal cancer in Balearic Islands and Barcelona. BMC Cancer 2010

10:500.

Submit your next manuscript to BioMed Central and take full advantage of:

- Convenient online submission

- Thorough peer review

- No space constraints or color figure charges

- Immediate publication on acceptance

- Inclusion in PubMed, CAS, Scopus and Google Scholar

- Research which is freely available for redistribution

Submit your manuscript at 